Paper for EGPA Annual Conference, Madrid, Spain, September 19-21 2007

EGPA Study Group 3: Public Personnel Policies

"Leadership, Professionalisation and HR Strategies"

\title{
Leadership diversity in an ageing workforce
}

\author{
Kathleen Vanmullem \\ Public Management Institute \\ Katholieke Universiteit Leuven \\ Parkstraat 45 - bus 3606 \\ B-3000 Leuven
}

Phone: +32 16323619

Fax: +32 16323611

Kathleen.vanmullem@soc.kuleuven.be

\author{
Prof. Dr. Annie Hondeghem \\ Public Management Institute \\ Katholieke Universiteit Leuven \\ Parkstraat 45 - bus 3606 \\ B-3000 Leuven \\ Phone: +32 16323607 \\ Fax: +3216323611
}

Annie.hondeghem@soc.kuleuven.be

\section{ABSTRACT}

As the population and the workforce are ageing, the average age of civil servants is increasing. Furthermore, the public sector generally has an older demographic profile than the private sector. New policies are required to attract workers and to motivate them to work longer (OECD, 2006b). Several models have been formulated to manage an ageing workforce. In each of these models, an essential role is placed upon leadership (Vanmullem and Hondeghem, 2005; Thijssen and Leisink, 2004; IImarinen, 2001; Walker and Taylor,1998). Leadership has to deal with the specific needs of a wide range of age groups in order to keep workers active and motivated as long as possible.

However, little research has been dedicated to the role of leadership in managing an age diverse workforce. Nevertheless the field of leadership has developed several perspectives to allow leadership diversity researchers to be creative in using much of its framework (DiTomaso and Hooijberg, 1996). In this paper, we use the leadership style theory to explore the relationship between leadership and the motivation of different age groups in the workforce.

In the first place, we review some theoretical issues concerning leadership and motivation. In the second place we discuss the data and methodology and the results of the analysis. Finally, we end this paper with a discussion of the results and some general conclusions. 


\section{Introduction}

As the population and the workforce are ageing, the average age of civil servants is increasing. Furthermore, the public sector generally has an older demographic profile than the private sector (OECD, 2006a). A demographic analysis of the Flemish government clearly illustrates the ageing of the workforce. One out of two civil servants is over 45 and one out of five is over 55. Many civil servants retire before the age of 65 , as it is possible to retire at 60 . As a result, approximately one in five older, experienced civil servants will leave the Flemish government in the next five years. It will not only be difficult to replace these persons, but it will also lead to a huge outflow of knowledge and experience. The labour shortage will force public and private organizations to keep their older workers active as long as possible.

Another consequence and challenge is the multigenerational workforce. Different generations work together, but each generation has specific needs and capabilities (Riccucci, 2002). As a result, managing an ageing workforce has become an urgent challenge for organization's human resource management (HRM). New policies are required to attract workers and to motivate them to work longer (OECD, 2006b). Several models have been formulated to manage an ageing workforce. In each of these models, an essential role is placed upon leadership (Vanmullem and Hondeghem, 2005; Leisink e.a., 2004; Ilmarinen, 2001; Walker and Taylor,1998). Leadership has to deal with the specific needs of a wide range of age groups (life course perspective) in order to keep workers active and motivated as long as possible. As effective leadership provides a sense of cohesiveness, personal development and higher levels of satisfaction among those conducting the work, it has a crucial role to fulfil (Montgomery, 2003). Management has to be aware of the differences among members of their workforce and try to create a working environment where each person can function at his or her best (Chen, 1996).

The considerable amount of research about leadership underlines the importance of the concept in organizational studies. However little research has been dedicated to the role of leadership in managing an age diverse workforce. Nevertheless the field of leadership has developed several perspectives to allow leadership diversity researchers to be creative in using much of its framework (DiTomaso and Hooijberg, 1996). In this paper, we use the leadership style theory to explore the relationship between leadership and the motivation of different age groups in the workforce.

First, we review some theoretical issues concerning leadership and motivation. Second we discuss the data and methodology and the results of the analysis. Finally, we end this paper with a discussion of the results and some general conclusions.

\section{Theoretical framework}

The theoretical framework provides some important concepts concerning leadership and motivation of workers. Leadership and motivation have been approached from various theoretical points of view. As Burns (1978) remarked : "Leadership is one of the most observed and least understood phenomena on earth". Yet, still we persist in trying to define and explain the concept. In times of rapid change and environmental complexity, leadership has taken a greater importance than ever before (Van Seters 
and Field, 1990). One of the primary tasks facing a manager is to motivate workers to perform to the best of their ability (Moorhead and Griffin, 1998). In the literature, motivation has been described in different ways and some research identifies changes in motivation during working life (Proenca and Shewchuck, 1998). In light of the growing interest in how to manage and motivate an ageing workforce, relatively little attention has been given to understanding the relation between ageing and work motivation (Kanfer and Ackerman, 2004) In this paper we link these concepts in an attempt to assess the impact of leadership on motivation of different age groups.

\section{Leadership}

Leadership is the ability to influence a group towards the achievement of its goals (Yukl, 2006). Many approaches have been used to advance the understanding of leadership.

Until the late 1970s transactional leadership was largely being studied, which stands for reciprocity or the idea that the relationship between leader and follower(s) is based on the exchange of some reward. A comparatively new leadership paradigm was proposed in the late 1970s transformational leadership. This new approach defines leadership as engaging the hearts and minds of others (Burns, 1978). In contradiction to Burns, Bass (1985) stated that transactional and transformational leadership do not exclude each other, as a leader can be both. The new approach of transformational leadership also gave an impetus to the study of administrative leadership in public administration (Van Wart, 2003).

Quite a large stream of the leadership literature investigates how different leadership styles affect groups' goal achievement (Barrow 1977, Yukl 1989). These leader behaviour studies precede the transformational approach in leadership theory. The field of leadership style theory includes two opposing positions: the universal and contingent leadership approach. Both perspectives describe leadership behaviour according to two broad dimensions: employee-relations orientation versus task, structure orientation (Arvonen 1999). The universal leadership approach states that a specific style is most effective in all kinds of situations. Authors such as Blake and Mouton (1964) assert that leaders scoring high on both dimensions perform better as leaders. The contingent leadership approach however states that the best leadership style is dependent on a number of situational contingencies. Hersey and Blanchard (1982) as the most famous agents of the situational theory, regard the maturity of the followers as the most crucial situational factor. The degrees of task orientation and relationship orientation need to be adapted to the maturity of a follower or group of followers in order to account for leadership effectiveness. The need for the leader to provide relational support increases while the need for task orientation declines as the follower's maturity increases. This might be an interesting avenue for further research in leadership diversity: as there might be a link between age and maturity of workers. This would imply that older workers have less needs of a task oriented, but more of a relations oriented leadership. Although some research state that age brings life experience and maturity (Chisholm and Bruns, 1999) (Super, 1980), there is so far however no clear link between age and maturity of people.

Including only two dimensions in the leader behaviour repertoire neglects the changing environment. Therefore Ekvall and Arvonen $(1991,1994)$ added a third dimension, namely a change/development 
orientated behaviour, finding that high scores on all three dimensions predicted high performance (Kornor en Nordvik, 2004).

For this paper we will use the CPE (Change, production and employee)-model of Ekvall and Arvonen (1999) to measure the three leadership styles, namely the task orientated (with a focus on achieving organizational goals), the relations orientated (with a focus on supporting and developing people) and the change orientated style (with a focus on development and change). The third dimension, which stresses the need to mobilize human resources in organizations, can be linked to transformative leadership (Burns 1978). We will measure the leadership styles experienced by the workers to gain insight into the role of leadership: does leadership style have an influence on the motivation of workers?

\section{Motivation}

The aim of an effective leadership style is to keep workers motivated by understanding their different values and needs. Motivation can be defined as the driving force behind the actions of an individual. Much of the research in organisational behaviour is linked to person-environment fit (P-E fit). The concept of P-E fit basically means that alignment between characteristics of people and their environment results in positive outcomes for both individuals and organizations (Livingstone and Nelson, 1997). The P-E fit has a long theoretical tradition, beginning with the interactionist perspective of Lewin $(1938,1951)$ who stated that behaviour is a function of the person and the environment (Chatman, 1989). The P-E fit concept resulted in several distinct constructs, all focusing on different aspects of the working environment. Person-environment fit has been defined as 'the compatibility between an individual and a work environment that occurs when their characteristics are matched' (Kristof-Brown et al $2005: 281$ ). One of these aspects is the person-supervisor fit: the dynamic relationship between individuals and supervisor in which the supervisor's personal characteristics represent the environment (Kristof and Brown, 2005).

Motivation theories can be divided into two main categories, namely 'content' and 'process' theories. Content theories concentrate on factors that determine motivation, while process theories treat motivation as a process, and emphasize how and why people choose certain behaviours in order to meet their personal goals. Goal setting is at the heart of motivation processes (Rainey, 1997). Vroom's 'Expectancy Theory' (1964) is an example of a process theory and seems to have a link with the P-E fit theory. The expectancy theory states that a worker's motivation depends on the degree to which a person wants something compared with the alternative choices and the rewards the person thinks s/he will receive. In brief, expectancy theory assumes that workers have several aims and their expectations determine their motivation. When an imbalance exists between what a person wishes ('want') and what a person receives ('get'), the person will try to handle this imbalance at the cost of his/her motivation. The central idea is that motivation depends on what workers want in their job and what they get. The bigger the imbalance between what one wants and what one gets, the bigger the chance of absenteeism, outflow, performance problems, etc. (Jurkiewicz, 1998). 
For this reason leadership has to gain insight into what motivates workers and what determines a worker's behaviour. An important role for management is to find out which job factors motivate workers and which resources, training or supervision are needed to realize a balance between 'want' and 'get'.

\section{Age}

In several West European countries, more attention is paid to the retirement of older workers, than to the investment in human capital of older workers. This results partly from the European welfare policy which has created financially attractive early retirement possibilities for older workers to make way for younger unemployed workers. This policy strengthens the prejudices against older workers and gives them a sign that it is better to leave as soon as possible, and reinforces the feeling of being an 'older worker' (OECD, 2000). The image of 'the older worker' is still too often dominated by stereotypes and prejudices such as "they are no longer motivated" or "they are not employable" and "they are just looking forward to retirement" (Rosen and Jerdee, 1976). Research findings, however, point out that despite some physical and cognitive decline, older workers compensate by using other resources and their experience. They are still employable (Marcoen, 2006). In contrast to what many people think, older workers are a very heterogenic group (Hassel and Perrewe, 1995). Age is an important factor, but it should not result in stigmatizing. The distinction is mostly made between 'young' and 'older' workers, but there is no clear definition of the 'older worker'. In Europe workers aged 45 are often defined as 'older worker' whereas in the USA an older worker is someone aged 60 or older. Not physical age, but a range of environmental factors influences the idea of who is an older worker. Research on worker age and performance suggests that age serves as a proxy indicator for a broad range of age-related processes that exert diverse and indirect effects on work outcomes (Kanfer and Ackerman, 2004). For this reason we also put this research in a lifespan perspective.

Most adults spend 40 or more years in the labour market. This lifespan is associated with major cognitive and intellectual changes that influence a person's functioning (Smith and Marsiske, 1994). This life-span approach, outlined by Paul B. Baltes (1997) says that development extends across the entire life course. Age-specific phenomena contribute to continuous (cumulative) and discontinuous (innovative) changes throughout life (Smith and Marsiske, 1994). As a result, physical, cognitive, psychological, socio cultural, family and other changes influence a worker's working behaviour (job satisfaction, absenteeism, performance, etc). In the literature, a lot has been written about 'changing capabilities and needs' through ageing, but there is no holistic and clear overview of what this exactly means and what the consequences are for management. The most discussed issues are: different training needs (Thijssen, 1995), adjustments in work content and physical work environment (IImarinen, 1999), greater importance of non-financial recognition and appreciation (Vanmullem and Hondeghem, 2005). Management has to be aware of these age-related changes and has to provide a work environment that recognises and accommodates the unique needs and capabilities of all workers to keep them active and motivated (Taylor and Walker, 1998). Although a lot of research has been done on motivation of public servants (Vandenabeele and Hondeghem, 2007; Karl and Sutton, 1998; Perry and Porter, 1982) there has been limited research, as far as we know, into the motivational factors of diverse age groups of civil servants. 


\section{Hypotheses}

Based upon these theoretical insights, some hypotheses concerning leadership and motivation can be formulated. We will specify some hypotheses to focus our empirical research.

First, leadership style has an influence on worker's motivation, defined as the balance between what a worker is expecting (wants) and what a worker is experiencing (gets) in the job.

Hypothesis 1: Leadership style has an effect on the discrepancy between 'want' and 'get'.

Second, age will be considered as a moderating variable integrated into the theory.

Hypothesis 2: The effect of leadership style on the discrepancy between 'want' and 'get' is moderated by age.

\section{Methods}

Survey and sample

This study is based on quantitative data derived from a web survey, which was conducted in 2006 in a Flemish public organization. The public organization provides assistance and advice on the well being of young children. Like most other organizations, this public organization is also confronted with an ageing workforce: $23 \%$ of the personnel is 50 years and over. All workers of the organization $(\mathrm{N}=1369)$ were asked to fill out a web survey. A total of 643 surveys were returned, a response rate of $47 \%$. The returned surveys were representative of the organization's population. Of the 643 respondents who returned the survey, 81 were in an executive function and 562 in a non-executive function. The organization has a mainly female workforce with only 1 in 10 public servants male. In our survey, 81 men and 562 women responded, which is respectively 13 and 87 percent of the total response. Each age group was well represented. There is only a slight under-representation of the civil servants at the lowest level (Level D).

\begin{tabular}{|l|l|l|l|l|}
\hline & Population & Respondents & \% Population & \% respondents \\
\hline Total & 1369 & 643 & & 46.9 \\
\hline Level A & 171 & 133 & 12.5 & 20.7 \\
Level B & 811 & 374 & 59.2 & 58. \\
Level C & 140 & 65 & 10.2 & 10.1 \\
Level D & 209 & 36 & 15.3 & 5.6 \\
\hline Executive & 106 & 81 & 7.7 & 12.6 \\
Non-Executive & 1263 & 562 & 92.3 & 87.4 \\
\hline Men & 143 & 81 & 10.4 & 12.6 \\
Women & 1226 & 562 & 89.6 & 87.4 \\
\hline Age 18-30 & 257 & 121 & 18.8 & 18.8 \\
Age 31-45 & 589 & 295 & 43.0 & 45.9 \\
Age 46-55 & 409 & 172 & 29.9 & 26.7 \\
Age 55 + & 113 & 47 & 8.3 & 7.3 \\
\hline
\end{tabular}

Table 1: analysis of the respondents by age, level, executive function and gender 


\section{Variables and measurement}

The questionnaire contained a variety of questions to measure the variables. Most of the questions used a likert scale For the purpose of this paper we only use the data relevant to measure the variables leadership style and motivation.

\section{Motivation}

We have defined 22 important job factors for public servants. Fifteen job factors come from the research of Jurkiewicz (1998) on the motivation of public servants and private workers. Additional job factors are taken from Depré and Hondeghem's research (1995) on motivation in the Belgian public service.

First, each respondent was asked to indicate the importance of the 22 job factors on a scale of 1 (not important) to 5 (very important). Second, each respondent was asked to mark the 22 job factors again, but now to what extent these job factors are present in their job, from 1 (totally not present) to 5 (totally present). The differences between 'want' and 'get' are, based on Vroom's expectancy theory, an indication of motivation. A substantial discrepancy between want and get can result in less motivation of the people who experience a gap. We only take the job factors with a first score ('want') higher than 4 into account, because these are the most important job factors for workers and will have a stronger effect on their motivation. The variable discrepancy is the mean of the difference of the 16 most important job factors.

\begin{tabular}{|l|c|c|c|}
\hline \multicolumn{1}{|c|}{ Job factors } & Want & Get & Discrepancy \\
\hline Friendly and congenial colleagues & 4.54 & 4.26 & 0.28 \\
\hline Support of colleagues & 4.53 & 4.10 & 0.43 \\
\hline A stable and secure future & 4.49 & 4.26 & 0.23 \\
\hline Chance to engage in satisfying leisure activities & 4.42 & 3.89 & $\mathbf{0 . 5 3}$ \\
\hline Chance to benefit well-being of children & 4.41 & 4.19 & 0.22 \\
\hline Chance to learn new things & 4.40 & 4.05 & 0.35 \\
\hline Clear communication & 4.39 & 3.22 & $\mathbf{1 . 1 7}$ \\
\hline Support of supervisor & 4.37 & 3.51 & $\mathbf{0 . 8 6}$ \\
\hline Freedom from pressures to conform both on and off the job & 4.30 & 3.36 & $\mathbf{0 . 9 4}$ \\
\hline Chance to benefit society & 4.29 & 4.03 & 0.26 \\
\hline Possibility to work autonomous & 4.27 & 3.99 & 0.28 \\
\hline Variety in work assignments & 4.25 & 3.78 & 0.47 \\
\hline Chance to use my special abilities & 4.18 & 3.69 & 0.49 \\
\hline Chance to have contact with the customers & 4.13 & 3.99 & 0.14 \\
\hline Chance to make a contribution to the objectives of the organization & 4.08 & 3.80 & 0.28 \\
\hline Working as part of a team & 4.06 & 3.97 & 0.09 \\
\hline
\end{tabular}

Table $2: 16$ Job factors to measure discrepancy

\section{Leadership style}

The questions on leadership style are based on the CPE-model (Arvonen en Ekvall, 1999). Fifteen items were used to measure the change, task and relation orientated leadership style. Each respondent was asked to assess the behaviour of his/her manager by assessing the 15 items. All these items were presented at random in a list. For each item there was a five- point scale ranging 
from 1 (totally inappropriate) to 5 (totally appropriate). Each item was an indication for a particular leadership style. The items for each style were:

\begin{tabular}{|c|c|}
\hline \multirow{5}{*}{$\begin{array}{l}\text { Change orientated leadership style } \\
(\text { alfa }=, 847) \text { (VARLG_C) }\end{array}$} & offers ideas about new and different ways of doing things \\
\hline & pushes for growth \\
\hline & initiates new projects \\
\hline & experiments with new ways of doing things \\
\hline & gives thoughts and plans about the future \\
\hline \multirow{5}{*}{$\begin{array}{l}\text { Task orientated leadership style } \\
(\text { alfa= ,696) (VARLG_T) }\end{array}$} & plans carefully \\
\hline & is very demanding about plans being followed \\
\hline & gives clear instructions \\
\hline & is controlling in his/her supervision of the work \\
\hline & makes a point of following rules and principles \\
\hline \multirow{5}{*}{$\begin{array}{l}\text { Relation orientated leadership style } \\
(\text { alfa }=, 917) \text { (VARLG_R) }\end{array}$} & shows regard for subordinates as individuals \\
\hline & is considerate \\
\hline & allows his/her subordinates to decide \\
\hline & trusts his/her subordinates \\
\hline & is friendly \\
\hline
\end{tabular}

Table 3: Leadership style

\section{Age}

We have divided the workforce into four age groups: 18-30 ( $n=121)$; 31-40 ( $n=180) ; 41-50$ ( $n=215)$; 50-65 $(n=118)$. This classification is based on statistical reasons. Other classifications would be too small for analysis and would lack the precision to provide reliable answers to the research questions. To be sure that our statistical test will have enough power, we have performed a special Power analysis (SAS 9.1 (c) PROC POWER). In order to have power above the recommended threshold of , 80 (Cohen, 1988), power analysis indicates that 82 subjects in each age group are necessary for both hypotheses.

Next to these variables a number of control variables were included in the analysis ('gender' and 'level'). The first one is gender, which is a dummy variable ( $1=$ man, $0=$ woman). The second is job level within the civil service, ranging from $D$ (the lowest level) to $A$ (highest level). For the correlation matrix, we have transformed this variable into an ordinal variable ranging from 1 (= level $D)$ to 4 (= level $A)$. The different age groups have also been defined as an ordinal variable in the correlation matrix ( $1=$ age 18-30; $2=31-40 ; 3=41-50 ; 4=51-65)$.

\section{Analysis}

The correlation matrix provides some interesting descriptive statistical results. In order to test our hypotheses, however, we need other statistical analyses. We use a regression analysis to examine the effects of the independent variables on the dependent variable in our model. Regression analysis is the most appropriate method for examining the relation between a set of independent variables and a single dependent variable. We used this method to test the effect of leadership style on motivation. Further multiple regression analysis is used to test the extent to which age moderates the relationship between the independent variable leadership style and the dependent variable motivation. 
These regression analysis were carried out for the whole population, but also for each age group separately. The statistical analyses are made with SPSS 15.0.

INSERT TABLE 4 HERE - correlation table

From the correlation matrix (table 4) we can conclude that all three leadership styles are negatively correlated with the discrepancy of the job factors. The more respondents experience a strong relation, change or task orientated leadership style of their supervisor, the smaller the discrepancy they experience for the job factors. The correlation between the discrepancy and the task orientated leadership style however is only half as strong $\left(r=-, 225^{\star *}\right)$ as the correlation between the discrepancy and the relation orientated $\left(r=-, 492^{\star \star}\right)$ and change orientated $\left(r=-, 432^{\star \star}\right)$ leadership style.

There is a weak positive correlation between job level of the respondent and the experienced discrepancy $\left(r=, 090^{\star}\right)$. The higher the job level, the more discrepancy in job factors. This result is inconsistent with other research findings. A possible explanation could be that people in the different levels experience other job factors as more important. To have more insight into these results further exploration is necessary.

The variables gender and age group have no significant correlation with the discrepancy. We want to point out however that we have transformed the age groups (18-30, 31-40, 41-50, 51-65) into an ordinal variable (ranging from 1 to 4 ) and that correlation analysis measures a linear relationship between the age groups and the discrepancy. If there is no linear relationship, this does not mean that there is no relationship at all.

The correlation analysis reveals also that civil servants at the higher levels experience less stronger leadership styles of their supervisor than civil servants at the lower levels. There is also a significant relation between gender and leadership style: men experience a stronger task orientated leadership style of their supervisor than women. It is also significant that there is a correlation between the job level and gender: the higher the job level, the more men. This is notable because $90 \%$ of the population in this organisation are women. Once again the phenomenon of vertical segregation is confirmed.

INSERT TABLE 5 HERE - regression H1

$\mathrm{H} 1$ is tested by means of a multiple regression analysis. The analysis (see table 5) presents a significant model, confirming $\mathrm{H} 1$. The three leadership styles and the control variables explain $26 \%$ of the variance in discrepancy ( $n=643)$. The control variables have no statistically significant effect on the discrepancy. Two out of three leadership styles demonstrate a significant influence. The change orientated $(-, 17)$ and the relation orientated $(-, 37)$ leadership style have a significant negative effect on the discrepancy. The influence of the relation orientated leadership style on the discrepancy is almost twice as big as the weight of the change related leadership style. 
With testing $\mathrm{H} 2$ we exam the interaction effect of 'age'. The moderated regression analysis shows that the effect of the leadership styles on the discrepancy differs substantially between the age groups. Only the relation orientated leadership style has a significant negative effect in all the age groups, the task orientated leadership style demonstrates no effect at all. The impact of the leadership styles is smallest in the youngest age group and is less than half compared to the other age groups. The older the workers, the bigger the influence of the relation orientated leadership style on the discrepancy a workers experiences.

For the youngest age group, the independent variables explain only $12 \%$ of the variance of discrepancy. For the other age groups, the three leadership styles and the control variables together explain 25\% and more of the variance. For the age group 31-40 and 41-50 the change and relation orientated leadership styles are both significant, but the relation orientated leadership style shows the most important influence. For the youngest and the oldest age group, respectively 18-30 and 51-65, only the relation orientated leadership style has a significant effect. The importance of the relation orientated leadership style is substantial for the age group 51-65. Older workers with a supervisor who has a strong relation orientated leadership style, have more chance to experience a lower degree of discrepancy between what they want and what they get out of the job.

In none of the age groups, is the discrepancy influenced by the control variables.

\section{Discussion}

This study investigates firstly the impact of leadership style on the discrepancy between what a worker wants and what a worker gets in the job and secondly the moderating effect of age on this relation. The goal was to bring two important areas of research, age diversity and leadership, together in order to understand better the impact of leadership on the motivation of the ageing workforce. Our model validates that leadership styles have a considerable effect on the discrepancy of job factors and that strong leadership styles are linked to a lower discrepancy rate. This supports Evkall and Arvonen's theory about leadership effectiveness. It also supports the general theoretical framework of an age related personnel policy (Vanmullem and Hondeghem, 2005), which states that the role of leadership is a crucial success factor in keeping workers employable and motivated. The analysis shows that the task orientated leadership style has no impact and that the relation orientated leadership style has the strongest influence. Again, this supports our theoretical model where the role of leadership in stimulating and supporting workers in their job (relation/people orientated) is a crucial factor (Vanmullem and Hondeghem, 2005). In this case the stronger a worker experiences a relation orientated leadership style, the smaller the discrepancy between what he/she expects and what he/she experiences in the job. As a result and based on Vroom's theory: the smaller the discrepancy, the bigger the motivation. The fact that the task orientated leadership style has no significant effect doesn't mean it has no influence on a worker's behaviour. In our research, we only looked at the effect on motivation, measured by means of the discrepancy between 'want' and 'get'.. 
This paper supplements existing leadership theory by stating that the effect of leadership styles differs between age groups. Results show that the effect of leadership styles is substantially lower for the youngest age group, compared to the other age groups where the effect increases as the workers are older. Once again, the relation orientated leadership style has a significant effect, and compared to the other leadership styles, has the strongest effect on the discrepancy in each age group. The change orientated leadership style also has a considerable effect on the middle-aged workers (aged 31-50). The different effects of the independent variables between the age groups illustrate the importance of a life course perspective, which considers the changing needs and capabilities of workers during their working life as a key factor. This result further supports the findings in the field of an age related personnel policy. One of the unanimous findings in research on ageing is the importance of recognition and appreciation of older workers in their work. The substantial effect of a relation orientated leadership style on the discrepancy experienced by older workers validates this statement in the literature. For younger workers, it is possible that organizational factors other than leadership style are more important and consequently have a bigger effect on the discrepancy. Each age group experiences other effects of the independent variables because of their different 'worlds'. This indicates the importance of age diversity management: management must have insight into the needs and capabilities of the different age groups and must try to accommodate this, for instance, through an adapted leadership style. To understand these different needs and capabilities, insight in the work values of the different age groups is necessary. In the literature, some are stating that these work values are influenced by generational experiences (Parker and Cusmir, 1991), while others state that these change over time with maturity. Those studies are scarce and their results are diverse. Smola and Sutton (2002) for example found a change in work values as generations matured but they also found other generational differences. Further research is needed here.

Like other research, our research has some limitations, which leads to suggestions for further research. First, we have defined discrepancy based on the 16 most important job factors of the whole population. Based on the life course perspective, it would be interesting to investigate if the most important job factors differ between the age groups. One could take a limited number of job factors into account (eg. the top five of the most important job factors) and examine if this list differs between the age groups. It would be interesting to see if the discrepancy with regard to this limited list leads to other results and could enhance the explanatory power of the regression models. Taking into account the differences between age groups would also lead to more specific information about the effect of the independent variables on the groups. In turn this would give more accurate information on how to manage different age groups.

Second, our research does not totally fit the universality theory which states that strong leadership styles are always most effective. In our research the impact of the styles differ between age groups. As Ekvall and Arvonen state 'even if some leadership profiles work well in general and some do less well, there could still be space for some contingency inside the best profiles or the worst profiles' (Evall and Arvonen, 1999:244). 
Third, further research should examine the effect of the discrepancy on the worker's behaviour (recruitment, career, retention). What is the indirect effect of leadership styles on the worker's intention to participate in training, to change job or to leave the organisation?

Fourth, we define the motivation of workers as the result of a discrepancy between what a worker is expecting and what a worker is experiencing. This is only one way to measure worker's motivation.

\section{Conclusions}

This study emphasises the importance of leadership style and is of added value to the research of 'age related personnel policy'. An ageing workforce creates interesting changes, both in attitudes and behaviours. Motivation is a core issue in keeping people active and employable. Our results highlight the fact that leadership style has an effect on the motivation of workers and that this effect differs between age groups. In an ageing society with an ageing workforce more attention needs to be paid to the different generations in the workforce and their specific needs. Leaders must move beyond their managerial or supervisor role and establish motivational environments that inspire followers to achieve levels of performance that meet the worker's expectations and perhaps exceed their initial beliefs in their own capabilities (Isaac, Zerbe en Pitt, 2001). Public organisations must adapt personnel practices and policies to respond to these changes. An age related personnel policy shapes the context in which leadership is able to better balance these personal and work goals of the worker.

\section{Bibliografie}

Arvonen, Jouko en Ekvall, Göran (1999) Effective leadership style: both universal and contingent. In: Creativity and innovation management. 8 (4), 242-250.

Baltes, P. B. (1997) On the Incomplete Architecture of Human Ontogeny: Selection, Optimization, and Compensation as Foundation of Developmental Theory. In: American Psychologist. 52, 366-380.

Barrow, J.C. (1977) The Variables of Leadership: A Review and Conceptual Framework. In: The Academy of Management Review. 2 (2), 231-251.

Bass, Bernard M. (1985) Leadership and performance beyond expectations. New York: Free Press.

Blake, R. R. and Mouton, J.S. (1964). The managerial grid. Houston: Gulf Publishing.

Burns, James MacGregor (1978). Leadership. New York: Harper and Row

Karl, Katherine A., and Cynthia L. Sutton (1998) Job Values in Today's Workforce: A Comparison of Public and Private Sector Employees. In: Public Personnel Management. 27(4), 515-27. 
Chatman, J. A. (1989) Improving interactional organizational research: A model of person-organization fit. In: Academy of Management Journal. 14: 333-349.

Chen, Chao C. and Van Velsor, Ellen (1996) New directions for leadership and practice in diversity leadership. In: Leadership Quarterly. 7 (2), 285-302.

Chisholm, Colin, U. and Burns, George, R. (1999), The role of work-based and workplace learning in the development of life-long learning for engineers. In: Global Journal of Engineering Education, 3 (3), 235-245.

Depré, Roger and Hondeghem, Annie (1995). Motivatie van ambtenaren: voorwaarde voor een efficient en effectief bestuur. Leuven: Federale diensten voor Wetenschappelijke, Technische en Culturele Aangelegenheden, V.C.O.B.

DiTomaso, Nancy and Hooijberg, Robert (1996) Diversity and the demands of leadership. In : Leadership Quarterly. 7 (2), 163-187.

Ekvall, G. and Arvonen, J. (1991) Change-centred leaders: Empirical evidence of a third dimension of leadership. In : Leadership and Organizational Development Journal. 12, 18-23.

Ekvall, G. and Arvonen, J. (1994) Leadership profiles, situation and effectiveness. In: Creativity and Innovation Management. 3, 139-161.

Hassell, B. \& Perrewe, P.L. (1995) An examination of beliefs about older workers: do stereotypes still exist? Journal of Organizational Behaviour. 16, 457-468.

Hersey, P. en Blanchard, K.H. (1969) Life cycle theory of leadership. In: Training and development Journal. 23 (5) 26-34.

IImarinen,I.J. (2001) Aging workers. In: Occupational and Environmental Medicine. 58, 546-552.

Isaac, Robert G.; Zerbe, Wilfred J. and Pitt, Douglas C. (2001) Leadership and motivation: The effective Application of expectancy theory. In : Journal of managerial issues. 13 (2), 212-226.

Jurkiewicz, Carole L.; Massey, Jr. Tom K.; and Brown, Roger G. (1998) Motivation in public and private organizations. A comparative study. In: Public productivity \& Management review. 21 (03), 230250. 
Kanfer, R. and Ackerman, P.L. (2004) Aging, adult development, and work motivation. In: Academy of Management Review., 29, 3, 440-458.

Karl, K.A., and Sutton, C.L. (1998) Job values in today's workforce: A comparison of public and private sector employees. In: Public Personnel Management. 27(4), 515-527.

Kornor, Hege and Nordvik, Hilmar. (2004) Personlity traits in leadership behaviour. In : Scandinavian journal of psychologie. 45 (1), 49-54.

Kristof-Brown, A. L., Zimmerman, R. D. and Johnson, E. C. (2005) Consequences of individual's fit at work: a meta-analysis of person-job, person-organozation; person-group and person-supervisor fit. In: Personnel psychology. 58, 281-342

Leisink, P., Thijssen, J. G. L. and Walter, E. M. (2004) Langer doorwerken met beleid. De praktijk van ouderenbeleid in arbeidsorganisaties. Utrecht: Utrechtse School voor Bestuurs- en organisatiewetenschap

Lewin, K. (1938) The conceptual representation and measurement of psychological forces. Duke university Press: Durham, NC.

Lewin, K. (1951) Field theory in social science. Harper: New York.

Livingstone, Linda P., Nelson, Debra L. and Barr, Steve H. (1997) Person-environment fit and creativity: an examination of supply-value and demand-ability versions of fit. In: Journal of Management. 23, 119-146.

Marcoen, A., Grommen, R. en Van Ranst, N. (2006) Als de schaduwen langer worden. Psychologische perspectieven op ouder worden en zijn. Leuven: LannooCampus.

Moorhead, G. and Griffen, R. W. (1998) Organizational behavior: Managing people and organizations. Boston, MA: Houghton Mifflin.

OECD (2000) Reforms for an ageing society. Social issues. Paris: OECD publications

OECD (2006a) The challenge of managing government employees in the context of an ageing population in OECD Member countries. Paris: OECD.

OECD (2006b) Live longer, Work longer. A synthesis report of the "Ageing and Employment Policies" project. Paris: OECD. 
Parker, B. and Cusmir, L.H. (1990) A generational and sex-based view of managerial work values. In: Psychological Reports, 66: 947-951.

Perry, James L., and Lyman W. Porter (1982) Factors Affecting the Context for Motivation in Public Organizations. In: Academy of Management Review. 7(1), 89-98.

Proenca, E. J. and Shewchuk, Richard M. (1998) Are older workers really different ? the effects of age, tenure, and education on work preferences of registered nurses. In: International Journal of Public Administration. 21, 11, 1603-1627

Rainey, H.G. (1997) Understanding and managing public organizations. San Francisco: Jossey-Bass

Riccuci, M. Norma. (2002) Managing diversity in Public Sector Workforces. Cambridge : Westview Press.

Rosen, B. and Jerdee, T. (1976) The influence of age stereotypes on managerial decisions. In: Journal of applied psychology. 61 (4), 428-432.

Smith, Jacqui and Marsiske, Michael (1994) Abilities and Competencies in Adulthood: Life-Span Perspectives on Workplace Skills. Philadelphia: National Center on Adult Literacy

Smola, Karen Wey and Sutton, Charlotte D. (2002) Generational differences: revisiting generational work values for the new millennium. In: Journal of Organizational Behaviour. 23, 363-382.

Super, D. E. (1980) A life span, life space approach to career development. In: Journal of Vocational Behavior, 13, 282-298.

Thijssen, J. G. L. (1996) Leren, leeftijd en loopbaanperspectief. Tilburg: Kathlolieke Universiteit Brabant.

Vandenabeele, W. and Hondeghem, A. (2007) Les dilemmes actuels posés par la motivation des fonctionnaires. In: Emery Yves \& Giaque David (Eds.). Nouveaux dilemmes de la GRH publique.) (in progress)

Vanmullem, Kathleen and Hondeghem, Annie. (2005). Een leeftijdsbewust personeelsbeleid: stand van zaken binnen het Ministerie van de Vlaamse Gemeenschap. Leuven : SBOV

Van Seters, David A. and Field, Richard H.G. (1990)The Evolution of Leadership Theory. In: Journal of organizational change management. 3 (3), 29-45. 
Van Wart, Montgomery (2003) Public-sector leadership theory: An assessment. In: Public Administration review. 63 (2), 214-228.

Vroom, V. (1964) Work and Motivation. New York: Jon Wiley \& Sons.

Walker, Alan and Taylor, Philip. (1998) Employers and older workers: attitudes and employment practises. In : Work \& Stress. Vol. 18. 641-658.

Yukl, G. (1989) Managerial Leadership: A Review of Theory and Research. In: Journal of Management. 15 (2), 251-289.

Yukl, G.A. (2006). Leadership in organizations. New Jersey: Prentice Hall. 
Pearson Correlation

\begin{tabular}{|c|c|c|c|c|c|c|c|c|c|}
\hline & Mean & S.D. & Diff_16 & VARLG_C & VARLG_T & VARLG_R & $\begin{array}{l}\text { Age } \\
\text { group }\end{array}$ & Level & Gender \\
\hline Diff_16 &, 60 & ,46 & 1 &,$- 432\left({ }^{\star *}\right)$ &,$- 225\left(^{* \star}\right)$ &,$- 492\left({ }^{* \star}\right)$ &,- 075 &, $090\left(^{*}\right)$ & 018 \\
\hline VARLG_C & 3,44 & ,87 & & 1 &, $507(\star \star)$ &, $\left.655{ }^{(\star \star}\right)$ & ,014 &,$- 168\left(^{(*}\right)$ & ,071 \\
\hline VARLG_T & 3,27 & ,73 & & & 1 &, $280\left(^{* \star}\right)$ & ,052 &,$- 273(* *)$ &, $192(* *)$ \\
\hline VARLG_R & 3,85 & ,88 & & & & 1 & ,007 &,$- 119\left(^{(*}\right)$ & ,038 \\
\hline Age group & 2,52 & 1,00 & & & & & 1 &,$- 099\left(^{*}\right)$ &,- 014 \\
\hline Level & 2,01 &, 75 & & & & & & 1 &, $155(* \star)$ \\
\hline Gender & 1,87 & ,33 & & & & & & & 1 \\
\hline
\end{tabular}

Table 4: Correlation Matrix 


\begin{tabular}{|c|c|c|c|c|}
\hline \multirow[b]{2}{*}{ Hypothesis 1 (a) } & & \multicolumn{2}{|c|}{ Unstandardized Coefficients } & $\begin{array}{l}\text { Standardized Coefficients } \\
\text { Beta }\end{array}$ \\
\hline & $\begin{array}{l}\text { (Constant) } \\
\text { VARLG_C } \\
\text { VARLG_T } \\
\text { VARLG_R } \\
\text { Gender } \\
\text { Level A } \\
\text { Level B } \\
\text { Level C } \\
\text { Adjusted R Square }\end{array}$ & $\begin{array}{l}B \\
1,732 \\
-, 087 \\
-, 023 \\
-, 188 \\
-, 056 \\
, 009 \\
-, 048 \\
-, 043 \\
, 256 * * *\end{array}$ & $\begin{array}{l}\text { Std. Error } \\
, 127 \\
, 028 \\
, 027 \\
, 025 \\
, 055 \\
, 082 \\
, 074 \\
, 087\end{array}$ & $\begin{array}{l}\text { Beta } \\
-, 169 * \star \\
-, 036 \\
-, 365^{\star \star \star} \\
-, 039 \\
, 008 \\
-, 052 \\
-, 029\end{array}$ \\
\hline $\begin{array}{l}\text { Hypothesis } 2 \text { (a) } \\
\text { AGE1830 }\end{array}$ & $\begin{array}{l}\text { (Constant) } \\
\text { VARLG_C } \\
\text { VARLG_T } \\
\text { VARLG_R } \\
\text { Gender } \\
\text { Level A } \\
\text { Level B } \\
\text { Level C } \\
\text { Adjusted R Square }\end{array}$ & $\begin{array}{l}\text { Unstanc } \\
\text { B } \\
1,758 \\
, 020 \\
-, 122 \\
-, 149 \\
, 054 \\
-, 197 \\
-, 266 \\
-, 209 \\
, 118^{* *}\end{array}$ & $\begin{array}{l}\text { ed Coefficients } \\
\text { Std. Error } \\
\text {,304 } \\
\text {,074 } \\
\text {,069 } \\
\text {,057 } \\
\text {,143 } \\
\text {,210 } \\
\text {,193 } \\
\text {,222 }\end{array}$ & $\begin{array}{l}\text { Standardized Coefficients } \\
\text { B } \\
, 036 \\
-, 215 \\
-, 300^{\star \star} \\
, 036 \\
-, 180 \\
-, 291 \\
-, 146\end{array}$ \\
\hline AGE3140 & $\begin{array}{l}\text { (Constant) } \\
\text { VARLG_C } \\
\text { VARLG_T } \\
\text { VARLG_R } \\
\text { Gender } \\
\text { Level A } \\
\text { Level B } \\
\text { Level C } \\
\text { Adjusted R Square }\end{array}$ & $\begin{array}{l}1,622 \\
-, 144 \\
, 029 \\
-, 162 \\
-, 187 \\
, 116 \\
, 101 \\
, 003 \\
, 257 * \star *\end{array}$ & $\begin{array}{l}\text {,258 } \\
\text {,051 } \\
\text {,057 } \\
\text {,044 } \\
\text {,096 } \\
\text {,206 } \\
\text {,204 } \\
\text {,229 }\end{array}$ & $\begin{array}{l}-, 291 * * \\
, 046 \\
-, 310^{\star \star \star} \\
-, 140 \\
, 120 \\
, 110 \\
, 002\end{array}$ \\
\hline AGE4150 & $\begin{array}{l}\text { (Constant) } \\
\text { VARLG_C } \\
\text { VARLG_T } \\
\text { VARLG_R } \\
\text { Gender } \\
\text { Level A } \\
\text { Level B } \\
\text { Level C }\end{array}$ & $\begin{array}{l}1,839 \\
-, 111 \\
-, 016 \\
-, 201 \\
, 023 \\
-, 063 \\
-, 100 \\
-, 063\end{array}$ & $\begin{array}{l}, 225 \\
, 050 \\
, 046 \\
, 045 \\
, 103 \\
, 117 \\
, 099 \\
, 121\end{array}$ & $\begin{array}{l}-, 206^{\star} \\
-, 023 \\
-, 389 * \star \star \\
, 015 \\
-, 056 \\
-, 112 \\
-, 048\end{array}$ \\
\hline & Adjusted R Square &, $285^{\star * *}$ & & \\
\hline AGE5165 & $\begin{array}{l}\text { (Constant) } \\
\text { VARLG_C } \\
\text { VARLG_T } \\
\text { VARLG_R } \\
\text { Gender } \\
\text { Level A } \\
\text { Level B } \\
\text { Level C } \\
\text { Adjusted R Square }\end{array}$ & $\begin{array}{l}1,419 \\
, 021 \\
-, 010 \\
-, 275 \\
, 138 \\
-, 104 \\
, 155 \\
, 106 \\
, 273^{\star * *}\end{array}$ & $\begin{array}{l}, 321 \\
, 062 \\
, 061 \\
, 063 \\
, 159 \\
, 264 \\
, 205 \\
, 238\end{array}$ & $\begin{array}{l}, 046 \\
-, 018 \\
-, 571 \text { }, 1 * \star \\
, 102 \\
-, 072 \\
, 151 \\
, 073\end{array}$ \\
\hline
\end{tabular}

\footnotetext{
Table 5: Regression analyses
} 